\title{
The incidence of leukaemia in women with BRCA1 and BRCA2 mutations: an International Prospective Cohort Study
}

\author{
Javaid lqbal ${ }^{1}$, Andre Nussenzweig ${ }^{2}$, Jan Lubinski ${ }^{3}$, Tomasz Byrski ${ }^{3}$, Andrea Eisen ${ }^{4}$, Louise Bordeleau ${ }^{5}$,
} Nadine M Tung ${ }^{6}$, Siranoush Manoukian ${ }^{7}$, Catherine M Phelan ${ }^{8}$, Ping Sun ${ }^{1}$, Steven A Narod ${ }^{*}{ }^{1}$ and The Hereditary Breast Cancer Research Group9

${ }^{1}$ Women's College Research Institute, Familial Breast Cancer Research, Toronto, ON M5G 1N8 Canada; ${ }^{2}$ Laboratory of Genome Integrity, National Cancer Institute, NIH, Bethesda MD 20892 USA; ${ }^{3}$ International Hereditary Cancer Center, Pomeranian Medical University, 70-111 Szczecin, Poland; ${ }^{4}$ Sunnybrook Regional Cancer Centre, Toronto, ON M4N3 M5 Canada; 5 Juravinksi Cancer Centre, Hamilton ON L8V 5C2 Canada; ${ }^{6}$ Beth Israel Deaconess Medical Center, Cancer Risk and Prevention Program, Boston, MA 02215, USA; 'Department of Preventive and Predictive Medicine, Fondazione IRCSS Istituto Nazionale dei Tumori, 20133 Milan, Italy and ${ }^{8}$ Department of Cancer Epidemiology, Moffitt Cancer Center, Tampa, FL 33647, USA

Background: Germline mutations in BRCA1 and BRCA2 increase the susceptibility to develop breast and ovarian cancers as well as increase the risk of some other cancers. Primary objective was to estimate the risk of leukaemia in BRCA1 and BRCA2 mutation carriers.

Methods: We followed 7243 women with a BRCA1 or a BRCA2 mutation for incident cases of leukaemia. We used the standardised incidence ratio (SIR) to estimate the relative risk of leukaemia, according to mutation and history of breast cancer.

Results: We identified five incident cases of leukaemia (two BRCA1, three BRCA2). All five women had a prior history of breast cancer and four had received chemotherapy. The mean time from breast cancer diagnosis to the development of leukaemia was 10.2 years (range 3-18 years). The SIR for BRCA1 carriers was $0.66(95 \% \mathrm{Cl}: 0.11-2.19, P=0.61)$ and the SIR for BRCA2 carriers was 2.42 (95\% Cl: 0.61-6.58, $P=0.17$ ). The SIR was significantly higher than expected for women with a BRCA2 mutation and breast cancer $(S I R=4.76,95 \% \mathrm{Cl}: 1.21-12.96, P=0.03)$, in particular for women who received chemotherapy $(S I R=8.11,2.06-22.07$, $P=0.007)$.

Conclusions: We observed an increased risk of leukaemia in women with a BRCA2 mutation who receive chemotherapy for breast cancer.

Germline mutations in the BRCA1 and the BRCA2 genes increase the susceptibility for a woman to develop breast and ovarian cancer (Miki et al, 1994; Wooster et al, 1995). Women with an inherited mutation in the BRCA1 or the BRCA2 gene have a life-time risk of $\sim 70 \%$ of developing breast cancer (Claus et al, 1996; Ford et al, 1998; Antoniou et al, 2003; Chen and Parmigiani, 2007; Mavaddat et al, 2013). Reports from the Breast Cancer Linkage Consortium suggested that women with BRCA1 and BRCA2 mutations have elevated risk of cancers other than breast and ovarian cancers (The Breast Cancer Linkage Consortium, 1999; Thompson et al, 2002). However, it is not clear to what extent a mutation in BRCA genes affects the risk of leukaemia. 
Cytotoxic chemotherapy for breast cancer is known to increase the risk of therapy-related myeloid neoplasms (Swerdlow et al, 2008). Chemotherapy-related myeloid neoplasms constitute up to $20 \%$ of all acute myeloid leukaemias and myelodysplastic syndromes (Morton et al, 2013). The National Surgical Adjuvant Breast and Bowel Project trials suggest that the use of an intense dose cytotoxic chemotherapy (such as adriamycin and cyclophosphamide), and radiation therapy for breast cancer is associated with a higher incidence of acute myeloid leukaemias, and myelodysplastic syndrome (Smith, 2003).

Most women who develop a BRCA1- or a BRCA2-associated breast cancer are likely to receive chemotherapy and radiation therapy. It is hypothesised that faulty mechanisms, such as altered cellular signalling, enhanced proliferation, diminished apoptosis, and abnormal differentiation increase the risk of chemotherapyrelated leukaemias and myelodysplastic syndromes in patients with the BRCA-associated breast cancer (Friedenson, 2007). Some case reports have suggested that mutations in BRCA1 or the BRCA2 gene might add to the risk of developing leukaemia in patients who receive chemotherapy and radiation therapy for their breast cancer (Fruscalzo et al, 2006; Cole and Strair, 2010). However, there are no prospective data on the subject.

We have previously reported on the incidence of pancreatic cancer, endometrial cancer, and colorectal cancer in $B R C A$ mutation carriers (Iqbal et al, 2012; Segev et al, 2013; Phelan et al, 2014). Here we report the incidence of leukaemia in a prospective cohort of $B R C A 1$ and the BRCA2 mutation carriers, and also estimate the incidence of leukaemia in women with a BRCA mutation who were treated with chemotherapy for breast cancer.

\section{MATERIALS AND METHODS}

Study cohort. We identified a total of 12310 women with a $B R C A 1$ or BRCA2 mutation through a registry of mutation carriers at the Women's College Research Institute, Toronto. The registry collects data from women who have a known pathogenic BRCA1 or BRCA2 mutation at 50 different centres in 11 countries in North America and Europe. The study protocol was approved by Ethics Committees/Human Subjects Review Boards of all participating centres. We obtained informed consent from all women before genetic testing. Mutation detection was confirmed by the direct sequencing of DNA.

Women were eligible for study entry if they were 25-74 years of age, and had a mutation in either the BRCA1 or the BRCA2 gene.
All BRCA carrier women had completed a risk assessment questionnaire at study entry and a follow-up questionnaire every 2 years thereafter. The questionnaires collected information on all new cancers diagnosed including site of cancer and age of diagnosis. At some centres, the questionnaires were completed by telephone interview. The eligible women completed at least one follow-up questionnaire. The diagnosis of leukaemia was confirmed by reference to a pathology report or medical record in all cases.

We excluded women who were $<25$ years $(n=454 ; 3.0 \%)$ and $>75$ years of age $(n=107 ; 0.71 \%)$ at baseline, who had no date of birth recorded $(n=5 ; 0.03 \%)$, who had not completed a follow-up questionnaire $(n=3,434 ; 22.9 \%)$, who were lost to follow-up $(n=986 ; 6.6 \%)$, and who had a missing date of death $(n=81$; 0.54 ), leaving 7243 women who were confirmed carriers eligible for study entry. We followed all women from the date of study entry (baseline) until either: 1) the date of completion of the last followup questionnaire, 2) diagnosis of leukaemia, and 3) death from any cause. Table 1 describes characteristics of study cohort.

Incidence and standardised incidence ratios. We estimated the incidence of leukaemia by dividing the total number of new leukaemia cases by the total person-years of follow-up. The incidence was calculated as rate per 100000 women per year. We calculated the risk of developing leukaemia in the BRCA1 and the BRCA2 mutation carriers relative to general population by calculating standardised incidence ratios (SIR). We calculated the SIRs in the following steps. First, we obtained incidence rates of leukaemia for each participating country using GLOBCAN 2012 (Ferlay et al, 2013). The incidence rates were calculated for each 5 -year age bins $(<40,40-44,45-49$, $50-54,55-59,60-64,65-69,70-74)$. Second, we calculated the number of person-years for each age bin in our carrier database. We then calculated the expected number of leukaemia cases for each age bin by multiplying incidence rate of leukaemia with person-years divided by 100000 . The SIRs were calculated as the ratio of observed cancers to expected cancers. The SIRs were calculated according to the type of BRCA mutation (BRCA1, BRCA2, combined), country of residence (Canada, Italy, Poland, and the United States), age groups $(<50$ years, $\geqslant 50$ years), breast cancer status (yes/no), and chemotherapy (yes/no) for breast cancer.

\section{RESULTS}

After a mean follow-up time of 6.1 years (range 1.0-19.5 years), five women (two BRCA1, three BRCA2) were diagnosed with

Table 1. Baseline characteristics of study cohort

\begin{tabular}{|c|c|c|c|c|}
\hline Characteristic & $\begin{array}{c}\text { All women } \\
N=7243\end{array}$ & $\begin{array}{c}\text { BRCA1 } \\
\mathbf{N}=5397\end{array}$ & $\begin{array}{c}\text { BRCA2 } \\
N=1790\end{array}$ & $\begin{array}{l}\text { Other }^{a} \\
N=56\end{array}$ \\
\hline \multicolumn{5}{|l|}{ Age, years } \\
\hline Mean (min, max) & $47.0(25-74.9)$ & $46.2(25-74.9)$ & $49.4(25-74.9)$ & $48.3(28-73)$ \\
\hline \multicolumn{5}{|l|}{ Breast cancer } \\
\hline Yes & 3200 & 2353 & 813 & 34 \\
\hline No & 4040 & 3042 & 976 & 22 \\
\hline Not known & 3 & 2 & 1 & 0 \\
\hline \multicolumn{5}{|c|}{ Chemotherapy $^{b}$} \\
\hline Yes & 2346 & 1776 & 540 & 30 \\
\hline No & 788 & 544 & 241 & 3 \\
\hline Not known & 66 & 33 & 32 & 1 \\
\hline \multicolumn{5}{|l|}{ Country } \\
\hline Canada & 2255 & 1229 & 994 & 32 \\
\hline Italy & 103 & 84 & 19 & 0 \\
\hline USA & 2185 & 1414 & 749 & 22 \\
\hline Poland & 2700 & 2670 & 28 & 2 \\
\hline
\end{tabular}


leukaemia. Table 2 presents characteristics of incident cases of leukaemia. Three women (one BRCA1, two BRCA2) were diagnosed with acute myeloid leukaemia and one woman (BRCA2) developed chronic lymphocytic leukaemia; one women (BRCA1) developed acute leukaemia but the subtype of leukaemia could not be determined. The mean age at diagnosis of leukaemia was 53.4 years. The mean age was 43 years for $B R C A 1$ mutation carriers and was 60.3 years for $B R C A 2$ mutation carriers.

All five leukaemia patients had previous history of breast cancer. The mean age at the diagnosis of breast cancer was 43.2 years $(B R C A 1=34.5$ years, $B R C A 2=49.0$ years). Four women (one $B R C A 1$, three $B R C A 2)$ received chemotherapy for their breast cancer. The BRCA1 mutation carrier who received chemotherapy for breast cancer developed acute myeloid leukaemia 3 years after initial treatment for breast cancer. Of three BRCA2 mutation carriers, two developed acute myeloid leukaemia after 18 and 10 years, and one patient developed chronic lymphocytic leukaemia 6 years after the treatment for breast cancer.

Overall, five cases of leukaemia were observed vs 4.3 cases expected ( $\mathrm{SIR}=1.16,95 \% \mathrm{CI}: 0.43-2.58, P=0.69)$. Among the entire cohort, the incidence of leukaemia was 11.3 per 100000 women per year. Two incident leukaemia cases were observed among the BRCA1 carriers vs 3.02 cases expected (SIR $=0.66,95 \%$ CI: $0.11-2.19, P=0.61$ ) (Table 3 ). For $B R C A 2$ carriers, three leukaemia cases were observed $v s 1.24$ cases expected $(\mathrm{SIR}=2.42$, 95\% CI: 0.61-6.58, $P=0.17)$. Among BRCA2 mutation carriers the incidence rate of leukaemia was 27.1 per 100000 women per year. Compared to the general population, the risk of leukaemia was higher for women $<50$ years $(\mathrm{SIR}=2.30,95 \% \mathrm{CI}$ : $0.38-7.59$, $P=0.27$ ); the risk was lower for women 50 years and above $(\mathrm{SIR}=0.87,95 \% \mathrm{CI}: 0.22-2.38, P=0.88)$. However, the absolute difference in the annual risk of leukaemia was statistically not significant between the two age groups $(P=0.77)$.

Compared to general population, the risk of leukaemia was fivefold higher for women who had a prior BRCA2-associated breast cancer (SIR $=4.76,95 \% \mathrm{CI}: 1.21-12.96, P=0.03$ ), but was not significantly higher for women with $B R C A 1$-associated breast cancer (Table 4). Among all women with BRCA-associated breast cancer who received chemotherapy, four cases of leukaemia were observed vs 1.4 cases expected ( $\mathrm{SIR}=2.86,95 \% \mathrm{CI}$ : 0.91-6.89,

Table 2. Characteristics of incidence cases of leukaemia in BRCA carriers

\begin{tabular}{|c|c|c|c|c|c|c|c|c|}
\hline Case no. & $\begin{array}{l}\text { Age at } \\
\text { breast } \\
\text { cancer } \\
\text { diagnosis }\end{array}$ & $\begin{array}{l}\text { Treatment } \\
\text { of breast } \\
\text { cancer }\end{array}$ & $\begin{array}{l}\text { Age at } \\
\text { leukaemia } \\
\text { diagnosis }\end{array}$ & Subtype of leukaemia & BRCA mutation & $\begin{array}{l}\text { Mutation } \\
\text { description }\end{array}$ & Status & Country \\
\hline 2 & 34 & $\begin{array}{l}\text { Surgery } \\
\text { Chemotherapy }\end{array}$ & 37 & Acute myeloid leukaemia (M3) & BRCA1 & Exon $12 \mathrm{Q} 1395 \mathrm{X}$ & Alive & Canada \\
\hline 3 & 52 & $\begin{array}{l}\text { Surgery } \\
\text { Chemotherapy } \\
\text { Tamoxifen }\end{array}$ & 70 & Acute myeloid leukaemia & BRCA2 & Exon 11 6024delTA & Dead & Italy \\
\hline 4 & 50 & $\begin{array}{l}\text { Surgery } \\
\text { Chemotherapy } \\
\text { Radiation } \\
\text { Tamoxifen } \\
\text { Letrozole }\end{array}$ & 60 & Acute myeloid leukaemia & BRCA2 & Exon 11 3772delTT & Alive & Canada \\
\hline 5 & 45 & $\begin{array}{l}\text { Surgery } \\
\text { Chemotherapy } \\
\text { Tamoxifen }\end{array}$ & 51 & $\begin{array}{l}\text { Chronic lymphocytic } \\
\text { leukaemia }\end{array}$ & BRCA2 & IVS24-18C >A & Alive & USA \\
\hline
\end{tabular}

Table 3. Observed and expected number of leukaemia cases in BRCA1 and BRCA2 carriers according to country of origin

\begin{tabular}{|c|c|c|c|c|c|c|c|c|}
\hline Country & $\begin{array}{l}\text { BRCA } \\
\text { status }\end{array}$ & $N$ & Person-years & $\begin{array}{l}\text { Observed } \\
\text { cancers }\end{array}$ & $\begin{array}{l}\text { Expected } \\
\text { cancers }\end{array}$ & $\begin{array}{c}\text { Incidence } \\
\text { (per } 100000 \\
\text { women) }\end{array}$ & SIR $(95 \% \mathrm{CI})$ & $P$-value \\
\hline \multirow[t]{2}{*}{ All combined } & All & 7243 & 44255.18 & 5 & 4.3 & 11.3 & $1.16(0.43-2.58)$ & 0.69 \\
\hline & BRCA2 & 1790 & 11074.09 & 3 & 1.24 & 27.1 & $2.42(0.61-6.58)$ & 0.17 \\
\hline \multirow[t]{2}{*}{ Canada } & All & 2255 & 16431.59 & 2 & 2.02 & 12.2 & $0.99(0.17-3.27)$ & 0.98 \\
\hline & BRCA1 & 1229 & 9211.06 & 1 & 1.05 & 10.8 & $0.95(0.02-5.31)$ & 0.56 \\
\hline \multirow{2}{*}{ Italy } & BRCA1 & 84 & 348.18 & 1 & 0.03 & 287.2 & $33.3(1.67-164.4)$ & 0.03 \\
\hline & BRCA2 & 19 & 115.14 & 1 & 0.01 & 868.5 & $100(5.0-493.2)$ & 0.01 \\
\hline \multirow[t]{3}{*}{ USA } & All & 2185 & 12343.86 & 1 & 1.30 & 8.1 & 0.77 (0.04-3.79) & 0.9 \\
\hline & BRCA1 & 1414 & 8379.13 & 0 & 0.87 & 0 & - & - \\
\hline & BRCA2 & 749 & 3862.16 & 1 & 0.43 & 25.9 & $2.33(0.12-11.47)$ & 0.42 \\
\hline
\end{tabular}


$P=0.07)$. Among women who did not receive chemotherapy, one case of leukaemia was observed $v s 0.83$ cases expected $(\mathrm{SIR}=1.20$, 95\% CI: 0.06-5.94, $P=0.76$ ) (Table 4).

The risk of leukaemia was eight-fold higher for women who received chemotherapy for a BRCA2-associated breast cancer $(\mathrm{SIR}=8.11,95 \%$ CI: 2.06-22.07, $P=0.007)$ (Table 5). For BRCA1 mutation carriers who received chemotherapy for breast cancer, the risk of leukaemia was similar to the risk in the general population (SIR $=0.97,95 \% \mathrm{CI}: 0.05-4.79, P=1.01)$. The absolute risk of leukaemia for women who received chemotherapy for breast cancer was $0.06 \%$ ( 1 of 1776 women) for the BRCA1 carriers and was $0.55 \%$ ( 3 of 540 women) for the BRCA2 carriers.

\section{DISCUSSION}

Women who carry a mutation in BRCA genes are concerned about their risk of developing cancers other than breast and ovarian cancers. In this prospective study of the $B R C A$ mutation carriers, we observed a two-fold increase in the risk of leukaemia among carriers of a BRCA2 mutation, compared to the risk in general population. The increased risk of leukaemia was statistically significant if a $B R C A 2$ mutation carrier had breast cancer (SIR $=4.69, P=0.03$ ), and had received chemotherapy $(\mathrm{SIR}=8.11, P=0.007)$.

The risk of leukaemia in the BRCA1 and the BRCA2 mutation carriers was first reported in the earlier studies of the Breast Cancer Linkage Consortium (The Breast Cancer Linkage Consortium, 1999; Thompson et al, 2002). In their first study, the Breast Cancer Linkage Consortium estimated the risk of leukaemia among the probable carriers of a BRCA2 mutation, relative to non-carriers, and subjects with an unknown mutation status (The Breast Cancer Linkage Consortium, 1999). The relative risk of leukaemia in probable carriers of the BRCA2 mutation was 1.12 (95\% CI: 0.30-4.25). The risk of leukaemia was relatively lower in the BRCA1 mutation carriers, compared to non-carriers and untested women (relative risk $=0.88$, 95\% CI: 0.37-2.14) (Thompson et al, 2002). Relative risks reported in studies of the Breast Cancer Linkage Consortium were based on the review of family histories, and diagnosis of leukaemia was based on the information provided by a family member. In comparison, our estimates are based on a prospective follow-up of women with a known BRCA mutation status.

Two case reports suggest that carriers of a BRCA2 mutation who receive treatment for breast cancer might be at a higher risk of developing haematologic malignancies, in particular, leukaemias (Friedenson, 2007; Cole and Strair, 2010). Fruscalzo et al (2006) reported of a patient who developed chronic lymphocytic leukaemia 2 years after receiving chemotherapy for the BRCA2associated breast cancer. In another case-series, Cole and Strair (2010) reported on six patients who developed either acute myelogenous leukaemia or myelodysplasia after receiving treatment for breast cancer. Three of six (50\%) patients in this caseseries had a mutation of one of the BRCA genes (BRCA1 or $B R C A 2$ ), and all of them received adriamycin and cyclophosphamide-based chemotherapy for their breast cancer. Hall et al (2006) reported acute myelogenous leukaemia in three Hispanic $B R C A 2$ carriers who did not receive chemotherapy or radiation therapy for early-stage breast cancers.

The actual risk of leukaemia in our BRCA cohort was $<1 \%$. One potential reason why the impact of $B R C A$ mutations on leukaemia incidence might be less than that for breast and ovarian cancer susceptibility could be that the self-renewal potential of leukaemic cells is dependent on genome stability, which is compromised when there is a BRCA mutation (Santos et al, 2014).

Our results are based on the prospective follow-up of the largest cohort of women who are confirmed carriers of a BRCA mutation, and with two-yearly follow-up of all women.

Our results should be interpreted with caution. Our BRCA cohort included only women and therefore we cannot estimate the incidence of leukaemia in male carriers of a $B R C A$ mutation. Moreover, the number of incidence cases was relatively small in our study which limits the precision of risk estimates for subgroups. Furthermore, missing follow-up information for nearly $30 \%$ women could potentially bias our estimates.

In conclusion, our findings suggest that women with a BRCA2associated breast cancer might be at a higher risk of developing leukaemia; in particular if these women receive chemotherapy for

Table 4. Observed and expected number of leukaemia in BRCA carriers according breast cancer status

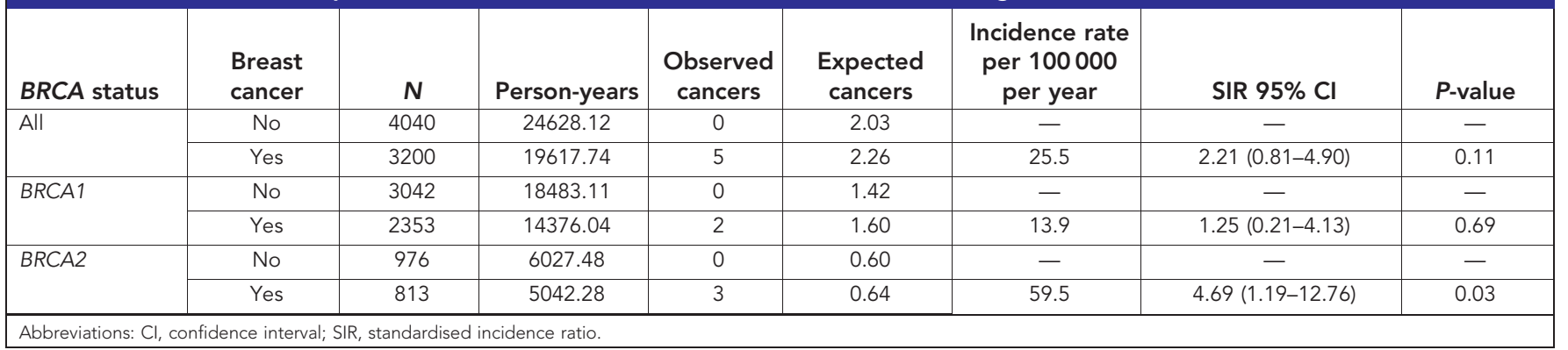

Table 5. Observed and expected number of leukaemia in BRCA-associated breast cancer patients according to chemotherapy

\begin{tabular}{|c|c|c|c|c|c|c|c|c|}
\hline BRCA status & Chemotherapy & $N$ & Person-years & $\begin{array}{c}\text { Observed } \\
\text { cancers }\end{array}$ & $\begin{array}{c}\text { Expected } \\
\text { cancers }\end{array}$ & $\begin{array}{l}\text { Incidence rate per } \\
100000 \text { per year }\end{array}$ & SIR $95 \% \mathrm{Cl}$ & $P$-value \\
\hline \multirow[t]{2}{*}{ All } & No & 788 & 5257.98 & 1 & 0.83 & 19.0 & $1.20(0.06-5.94)$ & 0.76 \\
\hline & Yes & 2,346 & 14107.09 & 4 & 1.40 & 28.3 & $2.86(0.91-6.89)$ & 0.07 \\
\hline BRCA1 & Yes & 1,776 & 10674.21 & 1 & 1.03 & 9.4 & $0.97(0.02-5.41)$ & 0.55 \\
\hline \multirow[t]{2}{*}{ BRCA2 } & No & 241 & 1662.88 & 0 & 0.27 & - & - & - \\
\hline & Yes & 540 & 3350.50 & 3 & 0.37 & 89.5 & $8.11(2.06-22.07)$ & 0.007 \\
\hline
\end{tabular}


breast cancer. However, given a very low actual risk, we suggest that the risk of leukaemia in the BRCA mutation carriers should not influence the choice of chemotherapy to treat their breast cancer.

\section{CONFLICT OF INTEREST}

The authors declare no conflict of interest.

\section{THE HEREDITARY BREAST CANCER STUDY GROUP}

Henry T Lynch, Cezary Cybulski, Susan Friedman, Leigha Senter, Jeffrey Weitzel, Christian Singer, Charis Eng, Gillian Mitchell, Tomasz Huzarski, Jeanna McCuaig, Dawna Gilchrist, Joanne L Blum, Dana Zakalik, Tuya Pal, Mary Daly, Carrie Snyder, Taya Fallen, Albert Chudley, John Lunn, Talia Donenberg, Raluca N. Kurz, Howard Saal, Judy Garber, Kevin Sweet, Christine Rappaport, Jacek Gronwald, Barry Rosen, Beth Karlan, Susan L Neuhausen, Pal Moller, Peter Ainsworth, Edmond Lemire, Dominique Stoppa-Lyonnet, Olufunmilayo I Olopade, Sofia Merajver, Carey A Cullinane, Eitan Friedman, Wendy McKinnon, Marie Wood, Daniel Rayson, Wendy Meschino, Josephine Wagner Costalas, Robert E Reilly, Susan Vadaparampil, Kenneth Offit, Noah Kauff, David Euhus, Ava Kwong, Claudine Isaacs, Fergus Couch, Christine Elser, Charmain Kim-Sing, Seema Panchal, Susan Armel, Rochelle Demsky, William D Foulkes, Andre Robidoux, Ellen Warner, Lovise Maehle, Gareth Evans, Barbara Pasini, Stephanie Cohen, Anna Jakubowska, Janice Little, Sonia Nanda, Kelly Metcalfe, Joanne Kotsopoulos, Aletta Poll, Marcia Llacuachaqui, Alejandra Ragone, and Ophira Ginsburg.

\section{REFERENCES}

Antoniou A, Pharoah PD, Narod S, Risch HA, Eyfjord JE, Hopper JL, Loman N, Olsson H, Johannsson O, Borg A, Pasini B, Radice P, Manoukian S, Eccles DM, Tang N, Olah E, Anton-Culver H, Warner E, Lubinski J, Gronwald J, Gorski B, Tulinius H, Thorlacius S, Eerola H, Nevanlinna H, Syrjäkoski K, Kallioniemi OP, Thompson D, Evans C, Peto J, Lalloo F, Evans DG, Easton DF (2003) Average risks of breast and ovarian cancer associated with BRCA1 or BRCA2 mutations detected in case series unselected for family history: a combined analysis of 22 studies. Am J Hum Genet 72: 1117-1130.

Chen S, Parmigiani G (2007) Meta-analysis of BRCA1 and BRCA2 penetrance. J Clin Oncol 25: 1329-1333.

Claus EB, Schildkraut JM, Thompson WD, Risch NJ (1996) The genetic attributable risk of breast and ovarian cancer. Cancer 77: 2318-2324.

Cole M, Strair R (2010) Acute myelogenous leukemia and myelodysplasia secondary to breast cancer treatment: case studies and literature review. Am J Med Sci 339: 36-40.

Ferlay J, Soerjomataram I, Ervik M, Dikshit R, Eser S, Mathers C, Rebelo M, Parkin DM, Forman D, Bray F (2013) GLOBOCAN 2012 v1.0, Cancer Incidence and Mortality Worldwide: IARC CancerBase No. 11 [Internet]. International Agency for Research on Cancer: Lyon, France, Available at http://globocan.iarc.fr. Accessed 2 June 2015.

Ford D, Easton DF, Stratton M, Narod S, Goldgar D, Devilee P, Bishop DT, Weber B, Lenoir G, Chang-Claude J, Sobol H, Teare MD, Struewing J, Arason A, Scherneck S, Peto J, Rebbeck TR, Tonin P, Neuhausen S, Barkardottir R, Eyfjord J, Lynch H, Ponder BA, Gayther SA, Zelada-Hedman M (1998) Genetic heterogeneity and penetrance analysis of the BRCA1 and BRCA2 genes in breast cancer families. The Breast Cancer Linkage Consortium. Am J Hum Genet 62: 676-689.

Friedenson B (2007) The BRCA1/2 pathway prevents hematologic cancers in addition to breast and ovarian cancers. BMC Cancer 7: 152 .
Fruscalzo A, Damante G, Calcagno A, Di Loreto C, Marchesoni D (2006) Four primary malignancies successively occurred in a BRCA2 mutation carrier: a case report. Cancer Invest 24: 611-614.

Hall MJ, Li L, Wiernik PH, Olopade OI (2006) BRCA2 mutation and the risk of hematologic malignancy. Leuk Lymphoma 47: 765-767.

Iqbal J, Ragone A, Lubinski J, Lynch HT, Moller P, Ghadirian P, Foulkes WD, Armel S, Eisen A, Neuhausen SL, Senter L, Singer CF, Ainsworth P, Kim-Sing C, Tung N, Friedman E, Llacuachaqui M, Ping S, Narod SA, Hereditary Breast Cancer Study Group (2012) The incidence of pancreatic cancer in BRCA1 and BRCA2 mutation carriers. Br J Cancer 107: 2005-2009.

Mavaddat N, Peock S, Frost D, Ellis S, Platte R, Fineberg E, Evans DG, Izatt L, Eeles RA, Adlard J, Davidson R, Eccles D, Cole T, Cook J, Brewer C, Tischkowitz M, Douglas F, Hodgson S, Walker L, Porteous ME, Morrison PJ, Side LE, Kennedy MJ, Houghton C, Donaldson A, Rogers MT, Dorkins H, Miedzybrodzka Z, Gregory H, Eason J, Barwell J, McCann E, Murray A, Antoniou AC, Easton DF (2013) EMBRACE. Cancer risks for BRCA1 and BRCA2 mutation carriers: results from prospective analysis of EMBRACE. J Natl Cancer Inst. 105: 812-822.

Miki Y, Swensen J, Shattuck-Eidens D, Futreal PA, Harshman K, Tavtigian S, Liu Q, Cochran C, Bennett LM, Ding W, Bell R, Rosenthal J, Hussey C, Tran T, McClure M, Frye C, Hattier T, Phelps R, Haugen-Strano A, Katcher H, Yakumo K, Gholami Z, Shaffer D, Stone S, Bayer S, Wray C, Bogden R, Dayananth P, Ward J, Tonin P, Narod S, Bristow PK, Norris FH, Helvering L, Morrison P, Rosteck P, Lai M, Barrett JC, Lewis C, Neuhausen S, Cannon-Albright L, Goldgar D, Wiseman R, Kamb A, Skolnick MH (1994) A strong candidate for the breast and ovarian cancer susceptibility gene BRCA1. Science 266: 66-71.

Morton LM, Dores GM, Tucker MA, Kim CJ, Onel K, Gilbert ES, Fraumeni Jr JF, Curtis RE (2013) Evolving risk of therapy-related acute myeloid leukemia following cancer chemotherapy among adults in the United States, 1975-2008. Blood 121: 2996.

Phelan CM, Iqbal J, Lynch HT, Lubinski J, Gronwald J, Moller P, Ghadirian P, Foulkes WD, Armel S, Eisen A, Neuhausen SL, Senter L, Singer CF, Ainsworth P, Kim-Sing C, Tung N, Llacuachaqui M, Chornokur G, Ping S, Narod SA,. Hereditary Breast Cancer Study Group (2014) Incidence of colorectal cancer in BRCA1 and BRCA2 mutation carriers: results from a follow-up study. Br J Cancer 110: 530-534.

Santos MA, Faryabi RB, Ergen AV, Day AM, Malhowski A, Canela A, Onozawa M, Lee JE, Callen E, Gutierrez-Martinez P, Chen HT, Wong N, Finkel N, Deshpande A, Sharrow S, Rossi DJ, Ito K, Ge K, Aplan PD, Armstrong SA, Nussenzweig A (2014) DNA-damage-induced differentiation of leukaemic cells as an anti-cancer barrier. Nature 514: 107-111.

Segev Y, Iqbal J, Lubinski J, Gronwald J, Lynch HT, Moller P, Ghadirian P, Rosen B, Tung N, Kim-Sing C, Foulkes WD, Neuhausen SL, Senter L, Singer CF, Karlan B, Ping S, Narod SA, Hereditary Breast Cancer Study Group (2013) The incidence of endometrial cancer in women with BRCA1 and BRCA2 mutations: an international prospective cohort study. Gynecol Oncol 130: 127-131.

Smith RE (2003) Risk for the development of treatment-related acute myelocytic leukemia and myelodysplastic syndrome among patients with breast cancer: review of the literature and the National Surgical Adjuvant Breast and Bowel Project experience. Clin Breast Cancer 4: 273-279.

Swerdlow SH, Campo E, Harris NL, Jaffe ES, Pileri SA, Stein H, Thiele J, Vardiman JW (2008) World Health Organization Classification of Tumours of Haematopoietic and Lymphoid Tissues. IARC Press: Lyon.

The Breast Cancer Linkage Consortium (1999) Cancer risks in BRCA2 mutation carriers. J Natl Cancer Inst 91: 1310-1316.

Thompson D, Easton DF,. Breast Cancer Linkage Consortium (2002) Cancer incidence in BRCA1 mutation carriers. J Natl Cancer Inst 94: 1358-1365.

Wooster R, Bignell G, Lancaster J, Swift S, Seal S, Mangion J, Collins N, Gregory S, Gumbs C, Micklem G (1995) Identification of the breast cancer susceptibility gene BRCA2. Nature 378: 789-792.

This work is published under the standard license to publish agreement. After 12 months the work will become freely available and the license terms will switch to a Creative Commons AttributionNonCommercial-Share Alike 4.0 Unported License. 